\title{
ДУХОВНО-МОРАЛЬНЕ ВИХОВАННЯ МОЛОДШИХ ШКОЛЯРІВ У КОНТЕКСТІ НОВОЇ УКРАЇНСЬКОЇ ШКОЛИ (НУШ)
}

\author{
Довженко Т. О.
}

доктор педагогічних наук, професор, декан факультету початкового навчання, Харківський національний педагогічний університет імені Г. С. Сковороди, м. Харків, Україна

\section{Небитова I.A.}

доктор філософії, координатор з виховної роботи факультету початкового навчання, Харківський національний педагогічний університет імені Г.С. Сковороди, м. Харків, Україна

У статті розглянуто проблему духовно-морального виховання молодших школярів у контексті Нової украӥнської школи (НУШ). На основі аналізу психолого-педагогічної літератури визначено сутність поняття «духовно-моральне виховання». Охарактеризовано основні завдання і чинники духовно-морального виховання молодших школярів.

Ключові слова: молодші школярі, духовно-моральне виховання, Нова українська школа, моральні норми, національні иүінності.

The article considers the problem of spiritual and moral education of junior schoolchildren in the context of the New Ukrainian School (NUS). Based on the analysis of psychological and pedagogical literature, the essence of the concept of "spiritual and moral education» is determined. The main tasks of spiritual and moral education of junior schoolchildren are described. The main factors of spiritual and moral education of junior schoolchildren are determined.

Key words: junior schoolchildren, spiritual and moral education, New Ukrainian school, moral norms, national values.

На сучасному етапі розвитку освіти в Україні суспільство може спостерігати якісні зміни освітнього простору. У Державному стандарті початкової освіти пріоритетним напрямком є духовно-моральне виховання учнів, яке передбачає прийняття молодшими школярами моральних норм і національних цінностей [2]. Зараз перед початковою школою постає завдання підготувати відповідального громадянина, який здатний об'єктивно оцінювати ситуацію і провадити власну діяльність відповідно до інтересів суспільства. Вирішення цього завдан- 
Розділ І. Ціннісні орієнтири духовно-інтелектуального виховання, розвиток духовно-інтелектуальних якостей особистості в умовах співпраці й інклюзії

ня пов'язано з формуванням стійких моральних якостей і моральних установок особистості молодшого школяра, тобто з правильною організацією духовно-морального виховання.

Проблема духовно-морального виховання завжди привертала увагу науковців. Раніше цю проблему вивчали такі видатні педагоги і психологи, як К. Ушинський, Я. Коменський, В. Караковский, Ш. Амонашвілі, В. Сухомлинський, І. Харламов, Л. Регуш та інші. Вони в своïx дослідженнях зверталися до проблеми формування оцінки і самооцінки моральної поведінки. Щодо сучасних досліджень, то проблему духовно-морального виховання молодших школярів відображено в наукових здобутках таких дослідників, як М. Алексич, А. Миронова, Н. Посмакова, В. Сластьонін тощо.

Зараз суспільство переживає моральну кризу, тому духовно-моральне виховання молодших школярів набуває дедалі більшої актуальності. Суспільство потребує особистостей, що володіють не тільки знаннями, а й моральними якостями, адже ще К. Ушинський говорив, що основу виховання дитини становить його моральна складова.

Вимоги до виховання школярів також описані у Державному стандарті початкової освіти. У цьому документі зазначено, що за час отримання школярами початкової освіти, має бути здійснено духовно-моральний розвиток і виховання учнів, яке передбачає прийняття ними моральних норм, національних цінностей і моральних установок [3].

Духовно-моральне виховання молодших школярів зараз є першочерговим завданням сучасної системи освіти в Україні, адже воно виступає важливим компонентом соціального замовлення для освіти. Це складний і багатоплановий процес.

3 огляду на Концепцію Нової української школи, духовно-моральне виховання молодших школярів повинно забезпечити:

- зміцнення моральності, яка заснована на свободі, волі та внутрішній установці особистості діяти у відповідності до своєї совісті;

- формування моралі як усвідомленої необхідності певної поведінки, що грунтується на уявленнях, які склалися в суспільстві про добро і зло;

- розвиток совісті як моральної самосвідомості особистості, здатності формулювати свої власні моральні обов'язки, а також здійснювати моральний самоконтроль і надавати моральну оцінку власним вчинкам і вчинкам оточуючих; 
- здатність до самостійних вчинків, які грунтуються на основі морального вибору і відповідальність за їх результати;

- усвідомлення цінності інших людей і цінність людського життя [5].

Слід зазначити, що духовно-моральне виховання - це цілеспрямований процес, що передбачає активну взаємодію вчителів та учнів. Цей процес спрямований на формування гармонійної особистості, а також на розвиток ціннісно-смислової сфери у процесі засвоєння духовно-моральних і національних цінностей, моральних і етичних норм поведінки в суспільстві [7].

Головною особливістю духовно-морального виховання молодших школярів є тривалість і безперервність. Це творчий процес, який досить часто коригується вчителями для його вдосконалення.

Основною ознакою духовно-морального виховання є його концентрична побудова: спочатку вирішуються завдання елементарного рівня, потім рівень підвищується. Цей принцип реалізується, враховуючі вікові особливості молодших школярів [1].

Видатний педагог В. Сухомлинський говорив, що основа духовноморальних переконань починає закладатися ще в дитинстві, коли добро і зло стають доступними для розуміння дитини лише за умови наочності, коли моральний сенс того, що учень спостерігає і робить, стає очевидним [6].

Зауважимо, що головним завданням духовно-морального виховання молодших школярів $є$ перетворення необхідних вимог суспільства у внутрішні стимули особистості кожної дитини (честь, обов’язок, совість, гідність тощо) [4].

Ефективність духовно-морального виховання молодших школярів багато в чому залежить від того, яким чином відбувається взаємодія між школою і сім'єю. Більшість батьків досить часто відвідують заклад освіти, в якому навчаються їх діти, на Новий рік, 8 березня, День захисників Вітчизни та інші заходи, що пов'язані з різноманітними святами. Класний керівник готує їх разом з батьками і учнями. У школі також можуть проводитися спортивні змагання, в яких може брати участь уся сім'я. Такі колективні заходи мають значний виховний вплив на особистість молодших школярів.

Окрім цього, безліч виховних заходів проводиться спільно з бібліотеками або будинками культури. Молодші школярі відвідують різні 
Розділ І. Ціннісні орієнтири духовно-інтелектуального виховання, розвиток духовно-інтелектуальних якостей особистості в умовах співпраці й інклюзії

гуртки, беруть участь в концертах і виставках, ходять на бібліотечні години тощо.

Дуже важливо виховувати в дітях щедрість, доброту, впевненість в собі і вміння насолоджуватися навколишнім світом. Усе це підготує учнів до дорослого життя і навчить оптимістично сприймати різні життєві ситуації.

Отже, система роботи, що спрямована на духовно-моральне виховання молодших школярів $є$ досить ефективною. У молодших школярів складаються товариські відносини між собою, вони рідко сваряться, навчаються швидко домовлятися один з одним, здатні самостійно вирішити між собою конфліктну ситуацію за допомогою комунікації, а також активно допомагають тим, кому потрібна допомога і дружно виконують загальні доручення. До того ж, у молодших школярів зростає інтерес до творчості, самостійного пошуку знань і мистецтва.

\section{Список використаних джерел:}

1. Алексич М. Школа изобразительного искусства : Учебное пособие. В 10 т. Т 1. Москва. Изобразительное искусство, 1990. 180 с.

2. Взаимодействие искусств в педагогическом процессе : межвуз. сб. науч. трудов. Санкт-Петербург : ЛГПИ, 2009. 155 с.

3. Державний стандарт початкової освіти URL : http://dano.dp.ua/attachments/ article/303/Державний\%20стандарт\%20початкової\%20освіти .pdf. (Дата звернення - 08.10.2021).

4. Миронова А. Коллективное творчество в изобразительной деятельности дошкольников. Молодой ученый. 2018. №10. С. 61-63.

5. Нова українська школа: порадник для вчителя. Київ : ТОВ «Видавничий дім «Плеяди». 2017. 206 с.

6. Посмакова Н. М. Значение игры для ребенка. Психология, социология и педагогика. 2013. №1. С. 15.

7. Сластенин В. Педагогика. Учеб. пособие для студентов высш. пед. учеб. заведений. Москва : Академия, 2002. 576 с. 